\title{
Pedagogies of Turkish Mosque Education in the Netherlands
}

\section{An Ethno-case Study of Mosque Classes at Milli Görüş and Diyanet}

\author{
Semiha Sözeri | ORCID: 0000-0002-3365-4831 \\ Department of Education and Pedagogy, Utrecht University, \\ Utrecht, The Netherlands \\ s.y.sozeri@uu.nl \\ H.K. Altinyelken | ORCID: 0000-0003-2178-0862 \\ Department of Child Development and Education, University of \\ Amsterdam, Amsterdam, The Netherlands \\ h.k.altinyelken@uva.nl
}

\author{
M.L.L. Volman \\ Department of Child Development and Education, University of \\ Amsterdam, Amsterdam, The Netherlands \\ m.l.l.volman@uva.nl
}

\begin{abstract}
This is a study of mosque pedagogies and their relevance for the formation of the moral and political identity of Turkish-Dutch youth. Based on fieldwork in two mosques affiliated with Milli Görüş and Diyanet in the Netherlands, the study identifies three different pedagogies practiced in the mosque classrooms: pedagogy of national identity building, unorthodox pedagogies of bonding, and pedagogies of moral formation. The findings show that teaching activities in both mosques contain messages pertaining to citizenship norms and values in areas such as interaction between different genders, ideas of crime, justice and punishment, relationship to authority and boundaries of individual autonomy. Apart from auxiliary use of Dutch and copying Dutch schools' motivation and discipline strategies, we did not find specific Dutch aspects of the education that was provided. The intention to create a pious and nationalist diaspora youth was a common denominator for the pedagogies of both mosques.
\end{abstract}




\section{Keywords}

Islamic education - Mosque classes - Turkish diaspora - Muslim youth - Diyanet Milli Görüş - The Netherlands

\section{Introduction $^{1}$}

Research on mosque education in Western societies - that is, the supplementary Islamic education provided by mosques for children with an immigrant background - is still in its infancy. This is a startling omission for a number of reasons. The first point to make is that providing Islamic education for the children in their congregation has always been one of the main activities of mosques around the world. This is a task that arguably gains more importance in diaspora conditions, which are characterised by parental worries about value transmission, identity maintenance across generations, and their children's cultural and religious assimilation (McCreery, Jones, and Holmes, 2007). Consequently, mosques become important actors in the value education and identity formation of Muslim children living in non-Muslim societies. Second, there is an indication that more Muslim children attend mosque classes than are enrolled in Islamic primary schools. For example, the latest figures from the Netherlands show that the total number of students enrolled in Islamic primary schools is 15,078 , although their ethnic background is not specified (DUO, 2018). On the other hand, mosque classes provided by only two of the Turkish Islamic communities in the Netherlands, Diyanet and Milli Görüş, are attended by approximately 20,00o students with a Turkish background (Sözeri and Altinyelken, 2019). Last but not least, recent studies have raised major concerns over the quality and relevance of mosque pedagogies not only in the Netherlands but also in other European contexts. Some have pointed out that deficits in quality are related to the lack of pedagogical training received by mosque teachers (Sieckelinck, Essousi, and El Madkouri, 2012), and the dominance of one-directional teacher-centred methods (Cherti and Bradley, 2011; Pels et al., 2016). Others have suggested that they fail to connect with the experiences of students growing up in non-Muslim societies, and counteract the pedagogical aims of mainstream schooling by inhibiting democratic dispositions, learner's autonomy and critical thinking (Coles, 2004; Halstead, 2018).

1 The research for this article has been funded by the University of Amsterdam. The coauthors work at the Department of Child Development and Education at the University of Amsterdam. 
Given the discrepancy between estimated student populations and the gravity of the concerns raised, the lack of empirical research on mosque education is remarkable.

Turkish mosque classrooms in the Netherlands are an interesting case: Dutch-Turks constitute the most numerous Islamic community in the country (СвS, 2018), and are found to be more self-contained than other migrant groups (Huijnk and Dagevos, 2012). Moreover, the Netherlands is exceptional in Europe for its drastic change from policies of multicultural accommodation to assimilationist policies that encourage immigrant integration (Entzinger, 2014). Following the adoption of this assimilationist policy stance, Islam was framed as the main source of migrants' 'incompatible cultural traits' (Duyvendak and Scholten, 2012), and the influence of mosques on Muslims' lives in the Netherlands was seen as undesirable (Sunier, 2016). Worries about the part played by mosque pedagogies in distancing young Muslims from the Dutch society were voiced in public debates by politicians of both the left and the right on the political spectrum (Besselink, 2014; Kouwenhoven and Holdert, 2019). It is therefore important to shed light on the pedagogies of mosque education because this could inform us about the teaching and learning practices that form the habitus of Turkish-Dutch youth beyond school. These practices contribute to the social reproduction of Muslim diaspora culture in Pierre Bourdieu's sense of the word: through the physical embodiment and internalisation of moral codes, attitudes and dispositions instilled by the (religious) institutions (Bourdieu, 1977).

We argue that the pedagogies of Turkish mosque education do not only strive to transmit Islamic knowledge and nurture the moral formation of the next generation in the diaspora context, but also aim to shape the political identity of Turkish-Dutch mosque students. Thus, the aim of this study is two-fold: to explore the relevance of mosque pedagogies for the formation of the moral and political identity of Turkish-Dutch youth, and to contribute to the emerging field of informal Islamic education by providing empirical insights into the pedagogical approaches employed at the mosques of two Turkish Islamic communities in the Netherlands, namely Diyanet and Milli Görüş. These are two of the most influential Islamic associations among the Turkish diaspora abroad. Like the majority of Muslims in the Netherlands and in the world more generally, they follow Sunni Islam. The main difference between them lies in their relationship with the Turkish state. While the Islamic Association Netherlands (Islamitische Stichting Nederland) has been the Dutch branch of the Turkish Presidency of Religious Affairs Diyanet since 1982, Milli Görüş has been set up by Turkish guest workers in Germany and the Netherlands as an 
Islamic association independent of the Turkish state in the 1970s. Although it is not directly affiliated with the Turkish state, Milli Görüş is representative of conservative political Islam in Turkey.

This article addresses the following questions: How does teaching and learning take place in mosque classrooms? What kind of pedagogical approaches are followed by mosque teachers in their lessons? And what do these pedagogies tell us about the formation of mosque students as moral and political subjects? To answer these, we use classroom observations and interviews with mosque teachers and imams collected during fieldwork at one Diyanet mosque and one Milli Görüş mosque. Our approach relies on the ethno-case study method, which combines characteristics associated with ethnography and case studies. It aims to provide a detailed in-depth description while recognising that the insights and conclusions drawn from the field constitute only a snapshot of a more complex and comprehensive picture.

\section{Mosque Education in the Netherlands}

There are approximately 500 mosques in the Netherlands (Hoorens et al., 2020 ) and virtually all of them provide some form of mosque classes. Of those, 148 mosque associations are affiliated with Diyanet, and 45 mosques with Milli Görüş. Nevertheless, as previously noted, empirical research on mosque education in the Netherlands is scarce. For the first research on the topic, the municipality of Rotterdam commissioned Trees Pels and her colleagues, who investigated the pedagogical practices of one Turkish and two Moroccan mosques in Rotterdam (Pels, Doğan, and El Madkouri, 2006; Pels, Lahri, and El Madkouri, 2006a; Pels, Lahri, and El Madkouri, 2006b). The researchers conducted classroom observations and interviews with parents, mosque teachers and students, and concluded that mosque education had undergone significant reforms since the initial stage of Muslim migrant settlement in the Netherlands in the 1980s. For instance, they found that teaching activities have become more child-friendly, discipline methods are less severe and there is less focus on rote learning than was previously the case. However, in all three mosques the researchers observed pedagogies that favoured one-directional exchange between mosque teachers and students (i.e. students were just expected to provide correct answers to teachers' questions). The researchers identified very little open interaction and discussion, which meant that pedagogies aimed at linking mosque education to the experiences of Muslim children in a Western country were absent. 
Later, in 2016, Pels and her colleagues conducted further research (Pels et al., 2016), commissioned by the municipality of Utrecht on the pedagogy of the Salafi AlFitrah Mosque, which had attracted negative media attention with reports of youth radicalisation. Their conclusions were similar to those of the previous research: lessons were taught in a positive pedagogical climate and the mosque association was providing mosque teachers with training in pedagogy, Islam and class management. However, again, little room for open dialogue and critical reflection was observed. While mosque teachers paid attention to the importance of students' social participation through education and work, they advised students always to adhere to Salafi norms and values even when they conflicted with the mainstream values of Dutch society. The researchers identified the pedagogy of mosque education in AlFitrah as authoritarian: it did not encourage interaction between the students, it prescribed a strict code of behavioural, and did not allow for discussion about information provided. Furthermore, students were advised to avoid contacts outside of their own religious group in order to minimize what were seen as undesirable impacts on their lifestyle, which the researchers considered to mitigate against students' social participation.

Lastly, a recent case study by Hülya Altinyelken and Semiha Sözeri (2019) based on a Diyanet mosque suggests that mosque pedagogies imported from the Muslim migrants' country of origin undergo significant adaptations in the diaspora context. Using classroom observations, and interviews with key stakeholders, imams, mosque teachers, parents and students, the study analysed the educational transfer of mosque pedagogy from Turkey to the Diyanet mosques in the Netherlands through imams appointed by the Turkish state and material developed for children in Turkey. The findings showed that, while the content of the classes largely overlapped with the curriculum of Quran classes at Diyanet mosques in Turkey, there were many local factors that reshaped the imported pedagogy and contributed to its re-contextualisation. The study found that some mosque teachers modified their pedagogical practices with the aim of mimicking mainstream education as closely as possible. This was done because the students responded best to practices into which they were already socialized, and because mosque teachers wanted students to take mosque education as seriously as the education they received in school. Examples of adaptation included copying the reward and punishment strategies followed in Dutch schools, using Dutch as auxiliary language in classes, increasing the use of interactive and play-based educational activities, offering extra-curricular activities and outings to aid group bonding, and making learning more inquisitive than was usual in in mosque education in Turkey. However, it was also found that, in the diaspora context, mosque pedagogy 
imported via Diyanet was intended not only to counteract religious assimilation, but also to socialise students into being loyal Turkish citizens.

The conclusions of Altinyelken and Sözeri (2019) need to be read together with the youth and education policies of consecutive AKP governments in Turkey. Since 2002, the conservative Islamist government of Recep Tayyip Erdoğan has a declared agenda to create a pious generation. Demet Lüküslü, who has examined the AKP's rhetoric and education policies that have been implemented to replace the secular Kemalist youth ideal with the pious Muslim youth ideal, points to the discursive othering of youth who are critical, protesting and rebellious. The goal of education policies is seen as raising young citizens who will be obedient to authority, de-secularised, neoOttomanist 'defender[s] of Islam', 'carrying a computer in one hand and Qur'an in the other' (Lüküslü, 2016: 638-40). Therefore, it seems reasonable to expect that these ideas would also be reflected in Diyanet mosque pedagogies in the Netherlands. Given their independence from the Turkish state, Milli Görüş pedagogies may have a different outlook. However, the political synthesis of Turkishness and Islam in the movement's ideology is likely to find its place in its mosque classrooms as well.

Critical scholars such as Mark Halstead (2018) who have analysed Islamic pedagogies from a Western liberal reference point have previously voiced concerns over the potential of mosque classes to alienate students from mainstream society by creating a tension between the 'diverse and incompatible' values taught at school and in the mosque (Halstead, 2018: 10). Halstead has also been critical of Islamic pedagogies for attributing unchallenged authority to the teacher and discouraging student autonomy and critical questioning. Similarly, Maurice Coles (2004) and Stijn Sieckelinck, Ahmed Essousi, and Halim El Madkouri (2012) have criticised mosque education for relying on untrained teachers who are unfamiliar with the Western context in which the children are growing up and for using outdated teacher-centred and disciplineoriented pedagogical approaches. These are seen as problematic because critical thinking, respect for diversity of opinion, and open classroom discussion with no pre-determined right or wrong answers are seen as some of the main pedagogical goals of citizenship education in schools (Schuitema et al. 2018).

To avoid essentialising Islamic pedagogy as a single approach applied in the same way across all Muslim communities, it seems to be more appropriate to talk about the diversity of Islamic pedagogies which are likely to vary not only across sectarian and ethnic lines, but also between congregations. Going back to the primary sources, as Claire Alkouatli does (2018), seems to provide some insights. For her study of the classroom practices of a mosque school in Canada, she analyses Islamic primary source texts (theological literature 
on the pedagogies in the Qur'an and the Sunna) and identifies three different types of Islamic pedagogy. Alkouatli calls these Relational Pedagogies, Pedagogies of Mutual Engagement, and Pedagogies of Conscious Awareness. The first category underlines the importance of building positive relationships between teachers and learners, and connecting to others in a warm, caring and compassionate way. Alkouatli maintains that differentiated learning and teaching is an important aspect of Relational Pedagogies, as building positive social relationships in the classroom can only be achieved by being considerate of the different learning needs of every student. Pedagogies of Mutual Engagement, on the other hand, stress the participatory and life-long nature of Islamic education for both students and teachers. This entails doing together (joining social practices and rituals together), speaking together (dialogue as a pedagogy) and inquiring together (questioning or searching for answers together). Lastly, Alkouatli defines Pedagogies of Conscious Awareness as teaching practices aimed at raising student awareness about the meaning and purpose behind the Islamic knowledge, practices and principles. These pedagogies go beyond classical teacher-centred instruction for the sake of 'cultivating conscious awareness for individual and social development' through critical reflexivity (Alkouatli, 2018: 13).

Here, we build on previous research by focusing more closely on the question of how teaching and learning take place in mosques in a Western country. In addition, we scrutinise the role of mosque pedagogies in the creation of moral and political youth identities. To explore the differences in teaching between state-organised and grassroots mosques, we add a comparative perspective by also including data from a mosque affiliated with Milli Görüş, which is arguably the second most prominent Turkish-Islamic association abroad after Diyanet.

The methodological approach adopted in this research can be best described as ethno-case study. The term has been developed by Marie Parker-Jenkins (2018), who argues that a new qualitative research design has emerged that combines the features of ethnographic research and a case-study. While ethnography has traditionally been used to generate rich and detailed descriptions of the lived experiences of a community based on the researcher's immersion in the field over a prolonged period of time ranging from months to years, the observations collected through a case study are more limited in time, possibly ranging from a few hours, to days or weeks. Acknowledging the limitations 
related to the time spent at the field means recognising that the study is part of broader context, conclusions drawn from the observed situations are bound to change in time, and shorter fieldwork might not be able to detect long-term patterns of change.

The data for this ethno-case study is based on three months of fieldwork (between March and May 2017) at one of the largest Diyanet mosques, and two months of fieldwork (between October and December 2017) at one of the largest Milli Görüş mosques in the Netherlands. In both cases, the mosques were not selected randomly by the researchers, but were chosen by the management or key figures within the respective Islamic associations. This implies that they are likely to contain best practice examples that the communities are willing to promote. Nevertheless, both mosques qualify as typical examples of the way teaching and learning take place in Diyanet and Milli Görüs mosques as curriculum content, learning goals and the training of mosque teachers is centrally defined in both associations.

The fieldwork involved nine classroom observations in eight classes attended by go students in total, and 1o semi-structured interviews with an educational coordinator, imams and mosque teachers. The classes were usually taught by unsalaried volunteers with diverse levels of expertise in Islamic education and pedagogy. We refer to them in this study as hoca [hodja], the Turkish term used to denote a mosque teacher. All of the hocas and imams, except two young female hocas at the Milli Görüş mosque, were born in Turkey. Below, Table 1 presents the characteristics of the hocas and imam at the Diyanet mosque, and Table 2 describes the hocas, imam and educational coordinator at the Milli Görüş mosque.

Four classrooms were observed in the Diyanet mosque, two for boys only, and two for girls only. This was also the case at the Milli Görüs mosque, where an additional fifth classroom was mixed. Below, Table 3 describes the composition of the classrooms observed at both mosques. Consent was obtained from the parents of the student participants in the study. Before the start of the fieldwork, the children themselves were also informed about the research, and they were given the opportunity to ask the researcher questions before and after the classroom observations. During the observations, the researcher sat at a separate desk at the back of the classroom and did not interfere in the classroom activities. While the main language of instruction was Turkish, each mosque had one classroom where the language of instruction was Dutch. The classroom observations paid attention to the physical conditions in the classrooms, curriculum content, classroom interactions, hoca and student activities, language use, the nature of asked questions and responses, classroom 
TABLE 1 Demographic characteristics of the hocas and imam at the Diyanet mosque

Sex Age Nationalities Education
Occupation Years of expe- Years of resirience at this dence in the mosque Netherlands

\begin{tabular}{|c|c|c|c|c|c|c|c|}
\hline Hoca1 & $\mathrm{F}$ & 40 & $\begin{array}{l}\text { Turkish \& } \\
\text { Dutch }\end{array}$ & $\begin{array}{l}\text { Vocational } \\
\text { education } \\
\text { degree for } \\
\text { Educational } \\
\text { Assistant }\end{array}$ & $\begin{array}{l}\text { Educational } \\
\text { assistant at } \\
\text { Dutch primary } \\
\text { schools }\end{array}$ & 6 & 20 \\
\hline Hoca2 & $\mathrm{M}$ & 45 & $\begin{array}{l}\text { Turkish \& } \\
\text { Dutch }\end{array}$ & $\begin{array}{l}\text { Bachelor's } \\
\text { degree in } \\
\text { Islamic } \\
\text { Theology }\end{array}$ & $\begin{array}{l}\text { Religious edu- } \\
\text { cation teacher } \\
\text { at Dutch pri- } \\
\text { mary schools }\end{array}$ & 4 & 17 \\
\hline Hoca $_{3}$ & F & 33 & Turkish & $\begin{array}{l}\text { Bachelor's } \\
\text { degree in } \\
\text { Islamic } \\
\text { Theology }\end{array}$ & $\begin{array}{l}\text { Female reli- } \\
\text { gious preacher } \\
\text { (Turkish state } \\
\text { employee) }\end{array}$ & 2 & 2 \\
\hline $\operatorname{Imam} 1$ & M & 33 & Turkish & $\begin{array}{l}\text { PhD in Islamic } \\
\text { Theology }\end{array}$ & $\begin{array}{l}\text { Imam } \\
\text { (Turkish state } \\
\text { employee) }\end{array}$ & 2 & 2 \\
\hline
\end{tabular}

climate, and power relations. The first author took detailed field notes of each observation.

The interviews focused on questions about classroom management, motivation and discipline strategies, Islamic pedagogies, and approaches to discussion and critical thinking. All the interviews were individual, conducted in a mosque classroom or imam's office, before or after the classes. The interviews lasted for an average of 40 minutes. All were audio recorded and transcribed verbatim, apart from the interview with one hoca at the Diyanet mosque. In that case, the first author took detailed notes of the interview. The respondents were given the choice to have the interview conducted in Dutch or Turkish, and most interviews took place in a combination of both. Quotations used in this study were translated into English by the first author. The thematic analysis and interpretation of the data were guided by the theoretical concepts of Islamic pedagogies and the academic criticisms of mosque education discussed in the literature. The researchers used a combination of deductive and inductive approaches to data coding: all data was coded using the concepts 
TABLE 2 Demographic characteristics of the hocas, imam and educational coordinator at the Milli Görüş mosque

Sex Age Nationalities Education Occupation Years of expe- Years of resirience at this dence in the mosque Netherlands

\begin{tabular}{|c|c|c|c|c|c|c|c|}
\hline $\mathrm{Hoca}_{4}$ & M & 49 & Turkish & $\begin{array}{l}\text { Bachelor's } \\
\text { degree in } \\
\text { Islamic } \\
\text { Theology }\end{array}$ & $\begin{array}{l}\text { Lecturer } \\
\text { at Islamic } \\
\text { University }\end{array}$ & 2 & 27 \\
\hline $\mathrm{Hoca}_{5}$ & $\mathrm{~F}$ & 19 & $\begin{array}{l}\text { Turkish } \\
\text { \& Dutch }\end{array}$ & $\begin{array}{l}\text { Vocational } \\
\text { high school } \\
\text { degree } \\
\text { for doctor } \\
\text { assistant }\end{array}$ & Unemployed & 3 & 19 \\
\hline
\end{tabular}

\begin{tabular}{|c|c|c|c|c|c|c|c|}
\hline Носа 6 & $\mathrm{~F}$ & 43 & $\begin{array}{l}\text { Turkish } \\
\text { \& Dutch }\end{array}$ & $\begin{array}{l}\text { Islamic voca- } \\
\text { tional high } \\
\text { school }\end{array}$ & Housewife & 6 & 17 \\
\hline $\mathrm{Hoca}_{7}$ & $\mathrm{~F}$ & 27 & $\begin{array}{l}\text { Turkish } \\
\text { \& Dutch }\end{array}$ & $\begin{array}{l}\text { Pedagogy } \\
\text { degree from } \\
\text { University } \\
\text { of Applied } \\
\text { Sciences }\end{array}$ & $\begin{array}{l}\text { Call center } \\
\text { agent }\end{array}$ & 2 & 25 \\
\hline Imam2 & M & 49 & $\begin{array}{l}\text { Turkish } \\
\text { \& Dutch }\end{array}$ & $\begin{array}{l}\text { Bachelor's } \\
\text { degree in } \\
\text { Islamic } \\
\text { Theology }\end{array}$ & Imam & 6 & 21 \\
\hline $\begin{array}{l}\text { Educational } \\
\text { coordinator }\end{array}$ & & 43 & $\begin{array}{l}\text { Turkish } \\
\text { \& Dutch }\end{array}$ & $\begin{array}{l}\text { Islamic } \\
\text { vocational } \\
\text { high school } \\
\text { \& vocational } \\
\text { degree as } \\
\text { Education } \\
\text { Assistant }\end{array}$ & $\begin{array}{l}\text { Educational } \\
\text { coordinator } \\
\text { of the mosque }\end{array}$ & 6 & 20 \\
\hline
\end{tabular}

and topics emerging from the literature, but the data was also (re-)read with the aim of identifying new patterns of meaning (themes) in relation to the explored research questions (Braun and Clarke, 2012). 
TABLE 3 Composition of the observed classrooms

\begin{tabular}{|c|c|c|c|c|c|}
\hline $\begin{array}{l}\text { Islamic } \\
\text { organisation }\end{array}$ & $\begin{array}{l}\text { Taught } \\
\text { by }\end{array}$ & $\begin{array}{l}\text { Age } \\
\text { range }\end{array}$ & Sex & $\begin{array}{l}\text { Number of } \\
\text { students } \\
\text { present }\end{array}$ & Lessons observed \\
\hline \multirow[t]{4}{*}{ Diyanet } & $\operatorname{Imam} 1$ & $10-16$ & Boys & 11 & $\begin{array}{l}\text { One Qur'an lesson and two } \\
\text { religious knowledge lessons }\end{array}$ \\
\hline & $H_{o c a} 1$ & $8-12$ & Girls & 13 & $\begin{array}{l}\text { Two Qur'an lessons and one } \\
\text { religious knowledge lesson }\end{array}$ \\
\hline & $\mathrm{Hoca}_{2}$ & $8-14$ & Boys & 13 & Three Qur’an lessons \\
\hline & $\mathrm{Hoca}_{3}$ & $8-14$ & Girls & 15 & $\begin{array}{l}\text { One Qur'an lesson and two } \\
\text { religious knowledge lessons }\end{array}$ \\
\hline \multirow[t]{5}{*}{ Milli Görüş } & Imam2 & $11-14$ & Boys & 9 & Hifz class: one Qur'an lesson \\
\hline & $\mathrm{Hoca}_{4}$ & $10-14$ & Boys & 13 & $\begin{array}{l}\text { Three religious knowledge } \\
\text { lessons }\end{array}$ \\
\hline & $\mathrm{Hoca}_{5}$ & $6-8$ & Mixed & 7 & $\begin{array}{l}\text { Preparatory class: One } \\
\text { Qur'an lesson and two reli- } \\
\text { gious knowledge lessons }\end{array}$ \\
\hline & Hoca 6 & $7-10$ & Girls & 9 & One Qur’an lesson \\
\hline & $\mathrm{Hoca}_{7}$ & $7^{-10}$ & Girls & 9 & $\begin{array}{l}\text { One religious knowledge } \\
\text { lesson }\end{array}$ \\
\hline
\end{tabular}

Education at both mosques was divided into two general subjects: Qur'an lessons focusing on learning to read the Qur'an in Arabic and memorisation of the prayers for namaz (a ritual prayer observed five times a day), and religious knowledge lessons focusing on the main tenets of the faith, the requirements for practising the religion, the history of Islam and the life of the Prophet. In addition, at the time of the fieldwork, the Milli Görüş mosque also had a hifz class comprised of advanced students learning to recite the Quran by heart. Of the 21 lessons observed, 11 were religious knowledge lessons, and 10 were Qur'an lessons, including the hifz class. It was observed that the hocas and imams employed different pedagogical approaches in the lessons, depending on whether they were teaching Qur'an or religious knowledge. Before delving into the different teaching strategies in these two subjects, it is important to give a perspective on the physical conditions in the mosque classrooms and 
underline some commonalities. Unlike school classrooms, the mosque classrooms were carpeted, and shoes were left in a special cabinet at the entrance of the mosque's education wing. On the walls of the classrooms, there were framed prayers in Arabic and Turkish, educational posters illustrating religious knowledge (e.g. how to perform ablution, i.e. the ceremonial washing of parts of the body before prayer, and the sequence of movements for namaz). In some cases, the walls were decorated with religiously inspired crafts and drawings made by students (at the Milli Görüş mosque), and the genealogy of the Ottoman sultans (at the Diyanet mosque). All but one of the observed mosque classrooms were equipped with a white board, bookshelves, school desks and chairs, in contrast to the typical mosque classroom setting where education takes place with both students and teachers seated on the ground with small wooden benches in front of them (Noh et al., 2014). Both mosques had at least one classroom with a projector, a computer and a printer. The only classroom that did not have a white board was actually a sohbet or religious discussion room, which one class was using temporarily until a regular classroom could be created for it. The management of both mosques complained about the lack of physical capacity to meet the demand for mosque classes, and both mosques had waiting lists for students. Some hocas commented on the importance of copying school classrooms as closely as possible so that the students felt comfortable at the mosque and did not regard it as an inferior learning environment. In all the classrooms, hocas and imams were seen to copy motivation and discipline strategies used in mainstream education (e.g. time-outs or staying after class as a discipline measure, and compliments, stickers and group outings as a motivation tool).

Before elaborating on the differences in teaching, it is important to note two other major differences between the mosques. The first has to do with the teaching materials used in the lessons. The Milli Görüş mosque had its own religious knowledge textbooks including special homework notebooks, grade sheets and teachers' books, with curriculum and certificates for completion for each level (beginners, intermediate and advanced), printed by Milli Görüş headquarters in Germany and distributed to all Milli Görüş mosques around Europe. The religious knowledge textbook for the advanced classes had a chapter dedicated to human rights which deals with concepts such as justice, liberty, equality, rights of minorities, freedom from gender and ethnic discrimination (IGMG, 2014: 210-20). This is indicative of the Milli Görüş vision, which promotes informed political awareness and engaged participation in European societies by its youth. The hocas at the Diyanet mosque, on the other hand, were relying on Islamic education textbooks usually used in Islamic secondary schools in Turkey and printouts of information that they would find 
online and bring to the class. ${ }^{2}$ We did not see any Diyanet materials tailored to the context-specific needs of diaspora youth. The second difference has to do with the availability of pedagogical training and support for the hocas teaching in the mosques. As reported by the hocas, educational coordinators and the management figures at Milli Görüş, all hocas teaching at Milli Görüş mosques receive annual pedagogical training which may last for a weekend or a week, and is taught by professional experts on child development and pedagogy. In addition, the case-study mosque had an in-house educational coordinator and pedagogue. The lack of similar arrangements for the hocas teaching at Diyanet was reported as a drawback by some of the hocas that we talked to, as they regarded the opportunities for training offered by Diyanet as inadequate. ${ }^{3}$

In the following sections we present three different pedagogies that we identified during our fieldwork: pedagogies of national identity building, unorthodox pedagogies of bonding, and pedagogies of moral formation. Lastly, to draw attention to the role of the characteristics of the hocas, we contrast the pedagogies of two different hocas within the same mosque.

\subsection{Pedagogy of National Identity Building: The Anthem, the Flag and the War Heroes}

Compared with religious knowledge lessons, Qur'an lessons in both mosques involved more self-study time balanced with one-to-one attention given by the hoca to individual students' proper pronunciation and reading skills. Qur'an lessons would start with a prayer said communally, followed by students taking turns to read passages from the Qur'an in Arabic and the hoca correcting their pronunciation. This was alternated with self-study time during which the hoca would work with each student individually while the rest of the class continued reading for themselves. Some Qur'an lessons, such as those given by Imam1 at the Diyanet mosque and the hifz class of Imam2 at the Milli Görüş

2 At the time of the fieldwork, the management of Diyanet commented that they were working on publishing bilingual religious education textbooks (in Turkish and the host country language, e.g. Dutch or German) for use in their mosque classrooms in Europe. However, these were not yet in use during the classroom observations. In 2018, the association reported on its website the publication of the first mosque education textbook "Camiye gidiyorum 1" ("I am going to the mosque 1 ") and the accompanying activity books: https://diyanet.nl/ hizmetlerimiz/dini-egitim-ve-din-hizmetleri/.

3 However, some indications emerged after the end of the fieldwork that Diyanet has also started to provide more training for their volunteer teachers. For example, the association mentions on its website a three-year training programme for mosque hocas that has been introduced as a pilot in some mosques (Hollanda Diyanet Vakfi, n.d.): https://diyanet.nl/ hizmetlerimiz/dini-egitim-ve-din-hizmetleri/. 
mosque, would start differently. Imam2, for instance, started by demonstrating to the students the proper way to recite the passage on which they would be working at the lesson. Imam1, on the other hand, followed a different strategy:

For the last two years when I come in the morning, I do something that never changes. I always start the lessons with Asma-ul-Husna. [...] Asma-ul-Husna are the 99 names of Allah. After we finish them, since those are children living abroad, I ask them to read the Turkish national anthem so that they can appreciate their fatherland and its flag. We read all ten verses. We stopped this exercise after each student had learnt the anthem by heart.

Imami, Diyanet mosque

Another Qur'an lesson at the same mosque began with a memorial prayer for the Turkish national war heroes who died at the Battle of Gallipoli during the First World War (classroom of Hoca2, Diyanet mosque). The war heroes were referred to as martyrs, implying they sacrificed their lives in the name of Islam. These practices show the importance attributed to instilling attachment to the Turkish Republic and maintaining Turkish national consciousness among diaspora youth to the extent that Islamic and Turkish identities are synthesised together and expressed in a pedagogy of national identity building.

The Quran lessons that were observed did not contain teaching strategies directed at encouraging debate or critical thinking; the nature of the subject material (i.e. learning to read and recite the Quran correctly) seems to be unconducive for such exercises. The pedagogies of these lessons thus overlapped to a great extent with the traditional image of mosque education. The importance of understanding the meaning of the Quranic passages that were read was underlined only in three of the Qur'an lessons. For example, Hoca3 and Imamı in the Diyanet mosque translated the meaning of the text at hand from Arabic to Turkish and wrote the main terms on the white board. When some students did not understand the Turkish words, the hoca and the imam asked the students who did understand to translate into Dutch for the rest. Similarly, Hoca6 at the Milli Görüş mosque said that she asked students to write down the meaning of the chapter they read in their notebooks because this way helps the students concentrate better. It is likely that Hoca3 and Imamı were able to provide Turkish translations and comment on the meaning since they were more highly educated than the others in Islamic theology and Arabic. Hoca6, on the other hand, relied on the translations available in the Islamic education textbooks. 


\subsection{Unorthodox Pedagogies of Bonding: Rapping in the Mosque and Imam's WhatsApp Group}

In contrast to the above, some of the hocas have incorporated innovative teaching practices in their Qur'an lessons. For example, Hoca2 has introduced an unorthodox approach to make reciting the Quran more entertaining for his students. He has allowed them to improvise rap music on the passages instead of reciting them in the traditionally accepted chant. The rapping took place at the end of the classroom observation, after which we talked with the student who had performed it. He explained that he used the music of the song Baba by the Turkish-Dutch rapper Rambo. This was a remarkable example of street culture (infamous for its foul language) entering the sacred space of the mosque classroom. This strategy seemed to facilitate better emotional connection between Hoca2 and his students. While Hoca2 still taught them reading and Qur'an recitation following the rules for correct pronunciation, he reserved the last quarter to half an hour of his classes to let them express themselves in a more creative way:

I try to teach without boring the child, avoiding classical instruction, but with stories and drama. [...] I think one of our main drawbacks right now is that we cannot afford to spend enough time on memorisation. If we do more memorisation, then morals and $a d a b$ [Islamic ethics], national and spiritual values education will lag behind. The children can memorise themselves, too. Conversation is more important. [...] Children view the mosque as an environment full of bans, they get bored and don't have fun. Therefore, we need more social activities to facilitate attachment to and love for the mosque. For example, I started a bike club. Also, the mosque offers Turkish language and music lessons.

Hoca2, Diyanet mosque

In another class, Imam2, teaching hifz at the Milli Görüş mosque, has incorporated technology in an innovative way when teaching Qur'anic recitation. His class has a WhatsApp group, and before studying a certain passage together, he sends them an audio or video recording of himself or someone else reciting the passage melodically. Correct intonation, rhythm and melody are central to learning to recite the Qur'an, so he expects them to have listened to the recording before the class. The WhatsApp group has also helped the class stay connected with each other and allowed the imam to bond with his students informally. When asked whether he observes any motivation or discipline issues at his classroom, he replies that he usually does not, but he has 
developed a strategy to teach unruly students one-to-one separately from their group until they correct their behaviour. Both rapping in the mosque classroom and integrating social media apps such as WhatsApp are examples of unorthodox pedagogies employed with the aim of establishing a better emotional connection with the students.

\subsection{Pedagogies of Moral Formation: Creating Pious Diaspora Youth}

Compared with the Qur'an lessons, the format of the religious knowledge lessons in both mosques was more conducive to discussion-based classes and featured more child-centred teaching strategies. Play-based instruction (e.g. using word games and puzzles to teach main Islamic concepts), storytelling (e.g. narrating stories from the life of the prophets), and using crafts (e.g. cutting and pasting paper with the names of the prophets or the angels on them) were the most commonly observed and reported teaching approaches. Religious knowledge lessons would begin with the hoca announcing the topic, followed by asking the students questions to assess what they remembered from the last lesson and whether they had studied at home. The hoca would write the main concepts on the white board, which was used much more actively during the religious knowledge lessons than during the Qur'an lessons.

The pedagogies employed in these lessons were noticeably guided by attention to the students' moral and spiritual formation. Hoca6 at Milli Görüş, for example, pointed out that what differentiates Islamic pedagogy and its approach to child development from the Dutch educational system is the importance it gives to teaching children to have respect for their parents, the elderly and family values. Similarly, Hoca3 at Diyanet, said that Islamic pedagogy was more concerned with the moral education of the children than the pedagogies she had observed in mainstream Dutch schools. Students who had been taught Islamic values and norms for proper social conduct would know what is acceptable for Muslim girls and boys with regard to sexual behaviour:

Excuse me, but there [at Dutch schools] a girl and a boy can sit next to each other, hold hands and kiss each other in the breaks. In other words, this is very normal there, but you can't do that in the spiritual atmosphere of the mosque. Because if the hocas are spending time to teach you knowledge, you have to respect them.

Hoca3, Diyanet mosque

Another aspect of moral formation was seen in discussions about following the Islamic dress code. Covering yourself and having special clothing for the 
mosque was seen as a necessary etiquette which the children should embrace as part of their education. This was also in line with the Islamic concept of embodiment: the expectation that the students would practise the Islamic knowledge they acquired (Hoca1, Diyanet mosque). Likewise, the pedagogy of practising together was observed in the classes taught by a number of Diyanet hocas, who stressed the importance of encouraging students to participate in namaz together with the congregation (Imamı and Hocal, Diyanet mosque).

\subsection{Same Mosque, Different Pedagogies: The Role of Hocas' Characteristics}

Among all the classroom observations, two contrasting approaches to teaching Islam stood out as examples that illustrate the extent of the diversity of pedagogies within the context of a single mosque. These were the religious knowledge lessons given by Hoca 4 and $\mathrm{Hoca}_{5}$ at Milli Görüş. To begin with, both hocas had very different profiles. Hoca4 was a 49-year-old man, a primary school graduate who migrated from Turkey when he was 22 years old and completed a private Islamic theology programme in the Netherlands. Hoca5, on the other hand, was a 19-year-old woman, born and raised in the Netherlands, who was a student in vocational training to be a medical assistant. Hoca 4 was teaching advanced-level boys whose age ranged between 10 and 14, and Hoca5 was teaching a preparatory class of boys and girls aged between six and eight. It was not only the mixed-gender composition that set the classroom of $\mathrm{Hoca}_{5}$ apart. Unlike than Hoca4, who used archaic Turkish mixed with Arabic words, she would use Dutch as the main medium of instruction complemented by Turkish. But what is more remarkable was her way of making the lessons more child-friendly and interactive.

Beside storytelling, crafts and educational games that were observed in other classes, she would also use body language, role-play and props to facilitate the students' learning. During our observation, for example, she started the lesson by holding an envelope and asking the students what they would use it for. They answered, 'to send a message'. She used the envelope as a prop to explain the concept of Allah sending messages to the people via the angels, as in the case of the angel Gabriel, who was the subject of that lesson. Another time, she would designated two students one of whom would demonstrate the ritual ablution, while the other would play the role of a hoca, checking whether the steps were performed correctly. Her teaching approaches were age-appropriate and conducive to enhancing student autonomy. This created a classroom climate in which the students felt relaxed about asking her challenging questions, as in the dialogue below: 
Hoca5: Paradise is a place that is much more beautiful than this earth. Student: How do you know? Have you ever been there?

Hoca5: This is what is written in the Qur'an.

Student: But I love play-stations. What if there are no play-stations in paradise?

Hoca5: They will give you everything you want in paradise.

Student: But what if what is written in the [holy] book is not true?

Hoca5: But this is not the topic of our lesson today. We are discussing the angels.

In contrast to this, the classroom of Hoca4 was characterised by an authoritarian teaching style and hierarchical power relations, with discipline and obedience expected from the students. Most of the talking was done by the hoca, who used rhetorical philosophical deliberation and storytelling to convey the messages of the lesson, which focused on fate and the role of human will in the pre-determined path dictated by Allah. Before starting to tell the story of the day, the hoca went to one of the students who was talking with his neighbour, grabbed his armed and pushed him lightly. The student and the rest of the group became visibly uncomfortable. After this, the hoca asked the students what could happen to someone just by touching him. For example, could someone be killed just by a touch? He then told them a story about the dream of a butcher who kills a customer just by touching him. The moral of the story was that the butcher would be legally accountable for his deed, but the death would have happened because of Allah's will. The storytelling appeared to aim at an aspect of personality development of the students. It conveyed political norms about justice and judgement by discussing accountability according to Islam and civil law. However, the story seemed to silence the students by creating an environment of fear. Following the classroom observation, in an interview with $\mathrm{Hoca}_{4}$ we asked him whether the students in his class ever asked critical or challenging questions, to which he replied: 'Last year there were questions such as "Why do I have to learn this", or "Why is this like that". But they got used to my style [...]. Right now, I don't have that problem anymore' (Hoca4, Milli Görüş mosque).

The examples above illustrate that, despite teaching the same subject in the same mosque, two hocas can have very different approaches to teaching. Although this was a Milli Görüş mosque, the pedagogies of the elderly, Turkey-educated Hoca 4 seemed to resonate with the ideal image of pious youth projected by the Turkish AKP government: obedient, respectful to authority and uncritical. During the fieldwork, the (female) educational coordinator of 
the Milli Görüş mosque commented that, although they kept an eye on what was happening in all the classes, had regular meetings and provided annual training for all hocas, they found it challenging to inspect the classes of elderly male hocas, and even more challenging to give them corrective feedback. Such internal power imbalances and the lack of external inspection might potentially have serious implications for the quality of mosque education and its impact on the lives of students.

\section{$5 \quad$ Discussion and Conclusion}

This study set out to reveal how teaching and learning takes place in Diyanet and Milli Görüş mosque classrooms in the Netherlands. It also examined the role of mosque pedagogies in the formation of mosque students as moral and political subjects. The analysis shows that, irrespective of the Islamic association they belong to, imams and hocas intend not only to transmit religious knowledge and instruction in how to read and recite the Qur'an, but also to teach children Islamic morals and codes of behaviour that will guide the students in their daily lives. Importantly, teaching activities in both mosques contained messages pertaining to citizenship norms and values in various areas such as interaction between the genders, ideas of crime, justice and punishment, relationship to authority and the boundaries of individual autonomy.

The primary-source pedagogies identified by Alkouatli (2018) were observed in many classrooms. For instance, all the Qur'an lessons had an element of differentiated learning (an aspect of Relational Pedagogies) expressed in oneto-one teaching of correct pronunciation. Similarly, the Pedagogies of Mutual Engagement expressed in 'doing together' were observed in encouraging the children to take part in the communal namaz, integrating educational games into the lessons, and organising social activities such as swimming, football and theme park trips together with the mosque class. The application of Pedagogies of Conscious Awareness through critical reflexivity was less pronounced as there were only a few cases in which the imam and hocas made space for critical questioning by the students. Some, like Hoca 4 , even defined it as a 'problem' that no longer occurred in his classes. In that sense, the findings imply that, despite attempts at copying mainstream education, mosque education might value certain aspects of school pedagogies more than others: while student autonomy is encouraged through self-study time and tasks in the classroom, challenging the tenets of the religion or the authority of the hocas might be seen as disrespectful and undesirable. This is in line with the findings of Pels and colleagues about the limited space for open dialogue in mosque classes 
(Pels, Doğan, and El Madkouri, 20o6; Pels, Lahri, and El Madkouri, 20o6a; Pels, Lahri, and El Madkouri, 20o6b; Pels et al., 2016). It also reinforces some of the concerns raised by Halstead (2018) about the potentially unfavourable impact of mosque pedagogies on students' critical thinking skills. One could argue that submission to the authority of the imam and the hocas might be a conscious choice made by the youngsters as individual agency and that the potential for resistance is not necessarily annihilated by the politics of piety (Mahmood, 2011), but this argument might not be sufficiently justifiable, given the young age of the mosque students.

On the other hand, the concerns raised by Coles (2004) and Sieckelinck, Essousi, and El Madkouri (2012) with regard to the hocas' lack of pedagogical training and the use of harsh discipline-oriented methods were only partially observed in our study. There is evidence of pedagogical reform and adaptations at both mosques. As Altinyelken and Sözeri (2019) have reported, the use of corporal punishment is said to have been eradicated in the mosques, and hocas in both Diyanet and Milli Görüss mosques borrow motivation, discipline and class management strategies from the Dutch schools. The availability of regular training and pedagogical support offered to hocas by their Islamic association appeared to be better arranged at the Milli Görüş mosque than at the Diyanet mosque. These seem to matter to the hocas and affect their perception of the quality of education they are providing.

The main language of instruction in both mosques was Turkish, and Dutch was used as a supplementary language, i.e. to translate some concepts (with the notable exception of the class of the young Hoca5). Apart from auxiliary use of Dutch and copying Dutch schools' motivation and discipline strategies, we did not find specific Dutch aspects of the education that was provided. The mosque classes that were observed could have taken place in any other Western country. The intention to create a pious and nationalist diaspora youth was a common denominator for the pedagogies of both mosques. While we observed unorthodox pedagogies of bonding and pedagogies of moral formation in both mosques, what sets their pedagogies apart is primarily the fact that the pedagogy of national identity building was observed to be more pronounced in the Diyanet classes in, for example, teaching the Turkish national anthem, and the memorial prayer for the Battle of Gallipoli, aimed at creating a nationalistic attachment to the Turkish state among the diaspora youth. In other words, our findings indicate that mosque pedagogies at Diyanet bring the political compass of diaspora youth more into line with Turkey than with the Netherlands. This was not observed to the same extent at the Milli Görüş mosque, where, in contrast, teaching materials gave attention to minority rights and the political participation of the youth in the countries where they 
are settled. These findings resonate with observations by Zana Çitak (2018), who argues that Diyanet's Islamo-nationalist rhetoric has been increasingly reflected in its activities that target Turkish citizens outside Turkey. Similarly, recent studies on Diyanet activities in Europe conclude that the Turkish state instrumentalises Diyanet mosques as one a tool by which to influence the Turkish diaspora (Maritato, 2018; Öztürk and Sözeri, 2018).

That said, although the literature suggests that Islamic pedagogies diverge along ethnic and sectarian lines, it has been remarkable to observe that there is a diversity of teaching approaches not only between different mosques within a single ethnic community, but also within mosques belonging to the same Turkish-Islamic association. As demonstrated by the comparison of the contrasting pedagogies in the classes taught by $\mathrm{Hoca}_{4}$ and $\mathrm{Hoca}_{5}$ at the Milli Görüş mosque, more standardised teaching material and availability of pedagogical training were not associated with harmonised teaching practices. Teaching experience in Dutch schools (as in the case of Hoca2 at Diyanet) seemed to be linked with more openness to innovation in mosque classes. This reinforces the findings of Altinyelken and Sözeri (2019) and Noh et al. (2014), who report that mosque teachers with experience in the mainstream education system adopt pedagogical practices from it and apply them in their mosque classes. However, the sample size and format of our study do not allow us to deduce underlying factors associated with the different pedagogies. It is likely that factors such as age, gender, country of birth, generation, exposure to the Dutch education system and level of education might have an influence on the extent to which the hocas and imams are open to deviate from traditional and more authoritarian Islamic pedagogies and make space for more childfriendly teaching practices. In his study on travelling Islamic preachers in the Netherlands, Daan Beekers (2015: 200-1) highlights that offering an appealing pedagogical space is as important as establishing religious authority, and observes that the pedagogical style of travelling preachers (who give talks in Dutch) 'tend[s] to resonate better with the life-world of young Muslims' than the traditional pedagogies of imams and mosque teachers. Research into such alternative informal Islamic pedagogical spaces (see also the 'implicit pedagogies' of affection in the extracurricular Islamic education of the Gülen community [Vicini, 2013]), and into the recruitment and training of hocas and imams might shed further light on this subject.

Last but not least, the implications of the difficulty of carrying out internal checks (e.g. due to power imbalances between female educational coordinators and male hocas), and the lack of external inspections, might have farreaching consequences for the quality of mosque education and its impact on students. Research shows that there is a demand for pedagogical innovation in 
mosque education, particularly by Muslim parents who were themselves born and raised in migration context (Pels et al., 2016), but also by hocas and imams who realise that mosque pedagogies imported from their countries of origin need to be adapted to the diaspora experiences of the children (Altinyelken and Sözeri, 2019). Cooperation with primary schools might help to achieve this: mosques have expressed a desire to establish pedagogical exchange programmes to collaborate with schools towards a shared pedagogical climate and creating a 'pedagogy of the neighborhood' (Pels, Lahri, and El Madkouri, 20o6a: 73). In this respect, our findings imply a need for further attention to the possibilities of and challenges to mutually beneficial pedagogical exchange and collaboration between mosques and schools that share a student population.

\section{References}

Alkouatli, C., "Pedagogies in becoming Muslim: Contemporary insights from Islamic traditions on teaching, learning, and developing", Religions, 9/11 2018), 367-85.

Altinyelken, H. K., and Sözeri, S., "Importing mosque pedagogy from Turkey: An analysis of contextual factors shaping re-contextualisation processes in the Netherlands", Comparative Education, 55/1 2019), 47-65. https://doi.org/10.108o/o3050068.2018.1 541666.

Beekers, D., "A moment of persuasion: Travelling preachers and Islamic pedagogy in the Netherlands", Culture and Religion, 16 (2015), 193-214.

Besselink, N., "PvdA'ers boos om toezicht Turkse clubs" [PvdA'ers angry about the monitoring of Turkish clubs]. Trouw, 13 November 2014.

Bourdieu, P., Outline of a Theory of Practice (Cambridge: Cambridge University Press, 1977).

Braun, V., and Clarke, V., "Thematic analysis", in H. E. Cooper, P. M. Camic, D. L. Long, A. T. Panter, D. E. Rindskopf, and K.J. Sher (eds), APA Handbook of Research Methods in Psychology, vol. 2: Research Designs: Quantitative, Qualitative, Neuropsychological, and Biological (Washington, DC: American Psychological Association, 2012), pp. 57-71.

CBS (Centraal Bureau voor de Statistiek), Jaarrapport integratie 2018 [Annual integration report 2018] (The Hague: Centraal Bureau voor de Statistiek, 2018).

Cherti, M., and Bradley, L., Inside madrasas: Understanding and Engaging with British-Muslim Faith Supplementary Schools (London: Institute for Public Policy Research, 2011).

Coles, M. I., Education and Islam: A New Strategic Approach (Leicester: School Development Support Agency, 2004).

Çitak, Z., "National conceptions, transnational solidarities: Turkey, Islam and Europe", Global Networks, 18/3 (2018), 377-98. 
DUO (Dienst Uitvoering Onderwijs), Leerlingen in het primair onderwijs [Students in Primary Education] [Data set]. 2018. https://duo.nl/open_onderwijsdata/databe standen/po/leerlingen-po/po-totaal/index.jsp.

Duyvendak, J. W., and Scholten, P., "Deconstructing the Dutch multicultural model: A frame perspective on Dutch immigrant integration policymaking", Comparative European Politics, 10/3 (2012), 266-82.

Entzinger, H., "The growing gap between facts and discourse on immigrant integration in the Netherlands", Identities, 21/6 (2014), 693-707.

Halstead, M., "Islamic education in the West and its challenge", in M. Woodward and R. Lukens-Bull (eds), Handbook of Contemporary Islam and Muslim Lives (Dordrecht: Springer International, 2018), pp. 1-15.

Hollanda Diyanet Vakfi, "Dini eğitim ve din hizmetleri" [Religious education and religious services], Hollanda Diyanet Vakfi, n.d. https://diyanet.nl/hizmetlerimiz/dini -egitim-ve-din-hizmetleri/, accessed 11 May 2020.

Hoorens, S., Nederveen, F., Snippe, J., de Muijnck, J., and Sijtstra, M., Onderzoek naar buitenlandse financiering van religieuze instellingen in Nederland [Research on foreign financing of religious institutions in the Netherlands] (Cambridge: Rand Europe, 2020).

Huijnk, W., and Dagevos, J., Dichter bij elkaar? [Closer together?] (The Hague: Netherlands Institute for Social Research, 2012).

IGMG (Islamische Gemeinschaft Milli Görüş), Temel bilgiler 3 [Fundamentals of religion 3]. (Cologne: IGMG, 2014).

Kouwenhoven, A., and Holdert, M., "In de koranschool leren kinderen dat Nederland niet hun land is" [In the Qur'an school the children learn that the Netherlands is not their country]. NRC, 10 September 2019. https://www.nrc.nl/nieuws/2019/o9/10/ in-de-koranschool-leren-kinderen-dat-nederland-niet-hun-land-is-a3972824.

Lüküslü, D., "Creating a pious generation: Youth and education policies of the AKP in Turkey". Southeast European and Black Sea Studies, 16/4 (2016), 637-49.

Mahmood, S., Politics of Ppiety: The Islamic Revival and the Feminist Subject. Princeton, NJ: Princeton University Press, 2011).

Maritato, C., "Addressing the blurred edges of Turkey's diaspora and religious policy: Diyanet women preachers sent to Europe", European Journal of Turkish Studies: Social Sciences on Contemporary Turkey, 27 (2018), 1-17.

McCreery, E., Jones, L., and Holmes, R., "Why do Muslim parents want Muslim schools?",. Early Years: An International Research Journal, 27/3 (2007), 203-19.

Noh, M. A. C., Tamuri, A. H., Razak, K. A., and Suhid, A., "The study of Quranic teaching and learning: United Kingdom experience", Mediterranean Journal of Social Sciences, 5/16 2014), 313-17.

Öztürk, A.E., and Sözeri, S., "Diyanet as a Turkish foreign policy tool: Evidence from the Netherlands and Bulgaria", Politics and Religion, 11/3 (2018), 624-48. 
Parker-Jenkins, M., "Problematising ethnography and case study: Reflections on using ethnographic techniques and researcher positioning", Ethnography and Education, 13/1 2018), 18-33.

Pels, T., Doğan, G., and El Madkouri, H., Pedagogiek in moskee Ayasofya [Pedagogy in the Ayasofya mosque] Utrecht: Verwey-Jonker Instituut/ForUM, 2006).

Pels, T., Hamdi, A., Klooster, E., Day, M., and Lahri, F., Pedagogiek Dar al-Hudaa: Een analyse van de pedagogiek van islamitisch onderwijs van de stichting AlFitrah. [Pedagogy of Dar al-Hudaa: An analysis of the pedagogy of Islamic education at the Association AlFitrah] (Utrecht: Verwey-Jonker Instituut, 2016).

Pels, T., Lahri, F., and El Madkouri, H., Pedagogiek in moskee Othman [Pedagogy in the Othman mosque] (Utrecht: Verwey-Jonker Instituut/FORUM, 2006a).

Pels, T., Lahri, F., and El Madkouri, H., Pedagogiek in moskee Al Wahda [Pedagogy in the Al Wahda mosque]. (Utrecht: Verwey-Jonker Instituut/FORUM, 20o6b).

Schuitema, J., Radstake, H., van de Pol, J., and Veugelers, W., "Guiding classroom discussions for democratic citizenship education", Educational Studies, 44/4 (2018), 377-407.

Sieckelinck, S., Essousi, A., and El Madkouri, H., "Improving after-school education in Dutch mosques: A matter of control or empowerment?", in K. Hicham, and B. Abdelhamid (eds), Social Work, Human Development and Empowerment of Skills: A Cross-Cultural Approach (Fez: APN, 2012), pp. 143-59.

Sözeri, S., and Altinyelken, H. K., "What are children being taught in the mosque? Turkish mosque education in the Netherlands", Learning, Culture and Social Interaction, 22 (2019), 1-13.

Sunier, T., "A tolerant social climate? Questioning the validity of an overly positive selfimage", in V. Mamadouh and A. van Wageningen (eds), Urban Europe: Fifty Tales of the City (Amsterdam: Amsterdam University Press, 2016), pp. 31-6.

Vicini, F., "Pedagogies of affection: The role of exemplariness and emulation in learning processes: Extracurricular Islamic education in the Fethullah Gülen community in Istanbul", Anthropology and Education Quarterly, 44/4 (2013), 381-98. 